\title{
A growing position of methanol and hydrogen as energy carriers in the global economy
}

\begin{abstract}
The changes taking place in the pool of materials available for the production of energy carriers and for the global chemical industry have been characterized. The report was prepared with due consideration of the growing population of our planet and the development of our civilization. The hydrogen production methods have been described. Subsequently, the research findings have been provided on catalytic hydrogenation of carbon dioxide to methanol and hydrocarbons in the Fischer-Tropsch synthesis process.
\end{abstract}

Key words: methanol, hydrogen, global economy

\section{Rosnąca pozycja metanolu i wodoru jako surowców energetycznych w gospodarce światowej}

W artykule scharakteryzowano zachodzace zmiany bazy surowcowej do wytwarzania nośników energii oraz dla światowego przemystu chemicznego, równolegle do rosnacego zaludnienia planety i rozwoju naszej cywilizacji. Opisano metody produkcji wodoru, zaprezentowano wyniki badań nad katalitycznym uwodornianiem ditlenku węgla do metanolu oraz węglowodorów metodą Fischera-Tropscha.

Słowa kluczowe: metanol, wodór, gospodarka światowa

\section{Introduction}

For many thousand years humanity has fulfilled its energy needs through biomass available in their natural habitat and cultivated through agriculture. A step forward in the development of our civilization was the use of the wind and tidal energy. Until the XIX century renewable energy resources constituted the basics in the developing world economics. Only the industrial revolution contributed to the rapid and multi directional application of coal in both power engineering and industry - mainly steelworks and chemical industry - for a variety of every day applications (medicines, paints, fertilizers, fibers, building materials etc.) In the last century the position of coal gradually weakened and gave way to crude oil and natural gas that were, at that time, relatively cheap and turned out to be highly economically effective materials in processing for power engineering and more widely, for the world economy. When the prices of crude oil began to grow in comparison to other nonrenewable energy carriers (this was related to the fact that the resources of crude oil are much smaller than those of coal and gas including hydrates), the technology of coal and gas refinement grew in popularity worldwide [1, 7]. This is presented in Fig. 1 and 2.

Currently, we use as much crude oil per annum as the amount of biomass processed in the soil in the period of a million years. At such a tremendous rate of exploitation of these crude oil natural resources it will be available for merely a few generations. In the years 1900-2000 the population of our planet grew 3.5 times and the use of primary energy carriers 13 times. When processing the nonrenewable energy carriers the emission of carbon dioxide grows. Currently, the emission of this toxic gas exceeds 24 billion tons per annum $[2,6]$.

\section{Wprowadzenie}

Ludzkość przez wiele tysiącleci zaspokajała swoje potrzeby surowcowo-energetyczne dostępną w otoczeniu oraz uprawianą w rolnictwie biomasą. Krokiem w rozwoju naszej cywilizacji było korzystanie $\mathrm{z}$ energii wiatru oraz wody. Do XIX wieku odnawialne źródła energii były podstawą postępującego rozwoju gospodarki światowej. Dopiero rewolucja przemysłowa przyczyniła się do szybkiego, wielokierunkowego zastosowania węgla tak w energetyce, jak i w przemyśle - głównie w hutnictwie oraz w przetwórstwie chemicznym - do różnorakich wyrobów powszechnego użytku (lekarstwa, farby, nawozy, włókna, materiały budowlane itp.). Na przestrzeni minionego wieku malała jednak pozycja węgla na rzecz ropy naftowej oraz gazu ziemnego, które były wówczas relatywnie tanie, a w dodatku okazały się surowcami, które można przetwarzać z większą efektywnością ekonomiczną zarówno w energetyce, jak i w gospodarce światowej. Gdy ceny ropy naftowej - w stosunku do pozostałych, nieodnawialnych nośników energii - zaczęły szybko wzrastać, co wiąże się z tym, że jej zasoby są wielokrotnie mniejsze od zasobów węgla oraz gazu ziemnego (łącznie z jego hydratami), to technologie uszlachetniania tych ostatnich zaczęły bardzo zyskiwać na ogólnoświatowym znaczeniu $[1,7]$. Prezentują je rys. 1 i 2 .

Obecnie zużywa się rocznie tyle ropy naftowej, ile biomasy $\mathrm{w}$ dalekiej przeszłości przetwarzało się $\mathrm{w}$ nią $\mathrm{w}$ ziemi na przestrzeni około miliona lat. Przy tak ogromnym eksploatowaniu podziemnych i podmorskich zasobów ropy naftowej będzie ona dostępna tylko kilku pokoleniom. Zaludnienie naszej planety w latach 1900-2000 zwiększyło się 3,5-krotnie, a zużycie pierwotnych nośników energii w tym 
The European Commission passed an Act dated 10.01.2007 on the limiting of the greenhouse effect to $2^{\circ} \mathrm{C}$ by 2020 . The realization of this task requires a radical reduction in the emission of the greenhouse gases by $50 \%$

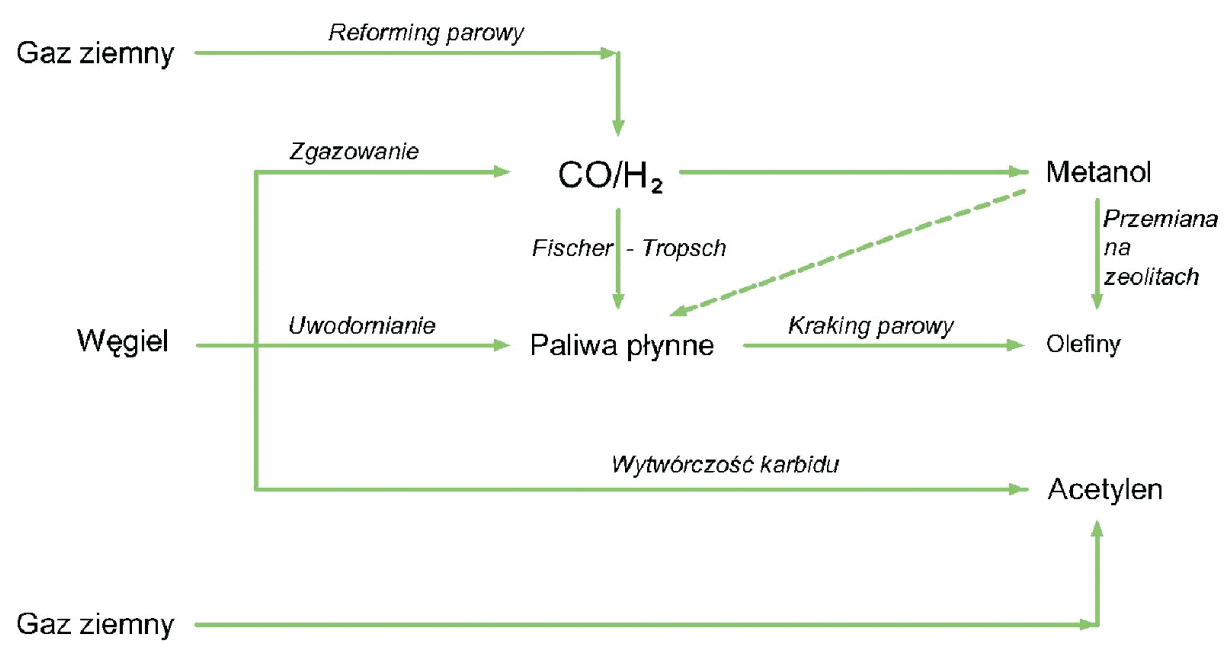

Fig. 1. Process operations for coal and natural gas conversion into liquid automotive fuels and to principal intermediates for the chemical industry [1]

Rys. 1. Operacje procesowe przetwarzania węla oraz gazu ziemnego do płynnych paliw silnikowych oraz głównych pótproduktów dla przemysłu chemicznego [1]

czasie wzrosło 13-krotnie. Przetwarzając - i to w rosnącej wciąż masie - nieodnawialne nośniki energii, emituje się do atmosfery coraz większe ilości ditlenku węgla. Obecnie emisja tego gazu przekroczyła 24 miliardy ton rocznie [2, 6].

Komisja Europejska, uchwałąz dnia 10.01.2007 r., wnioskuje o ograniczanie globalnego ocieplania naszej planety do $2^{\circ} \mathrm{C}$ w perspektywie roku 2020 oraz dalszej. Realizacja tego zadania wymaga radykalnej redukcji emisji gazów cieplarnianych o $50 \%$ do 2050 r. - w tym w krajach rozwiniętych o $30 \%$ do roku 2020.

Uznano, że elementem koniecznych działań stają się prace badawczo-wdrożeniowe nad wydzielaniem ditlenku węgla z gazów przemysłowych oraz ze spalin wraz z jego transportem i składowaniem (sekwestracją) w formacjach geologicznych. Są to kosztowne oraz energochłonne procesy, które spowodują odczuwalny wzrost cen prawie wszystkich wyrobów

by 2050 - including economically developed countries by $30 \%$ by 2020 .

One of the vital elements are research and development works on the emission of carbon dioxide from industrial gases and exhaust including such issues as its storage and sequestration in geological formations. These are costly and energy consuming processes that will inevitably result in higher prices of almost all the final products. What is more, these operations have not yet been fully verified in any of the participating countries and we do not know whether they are safe in the long run. In such a situation we have to take into consideration the production of

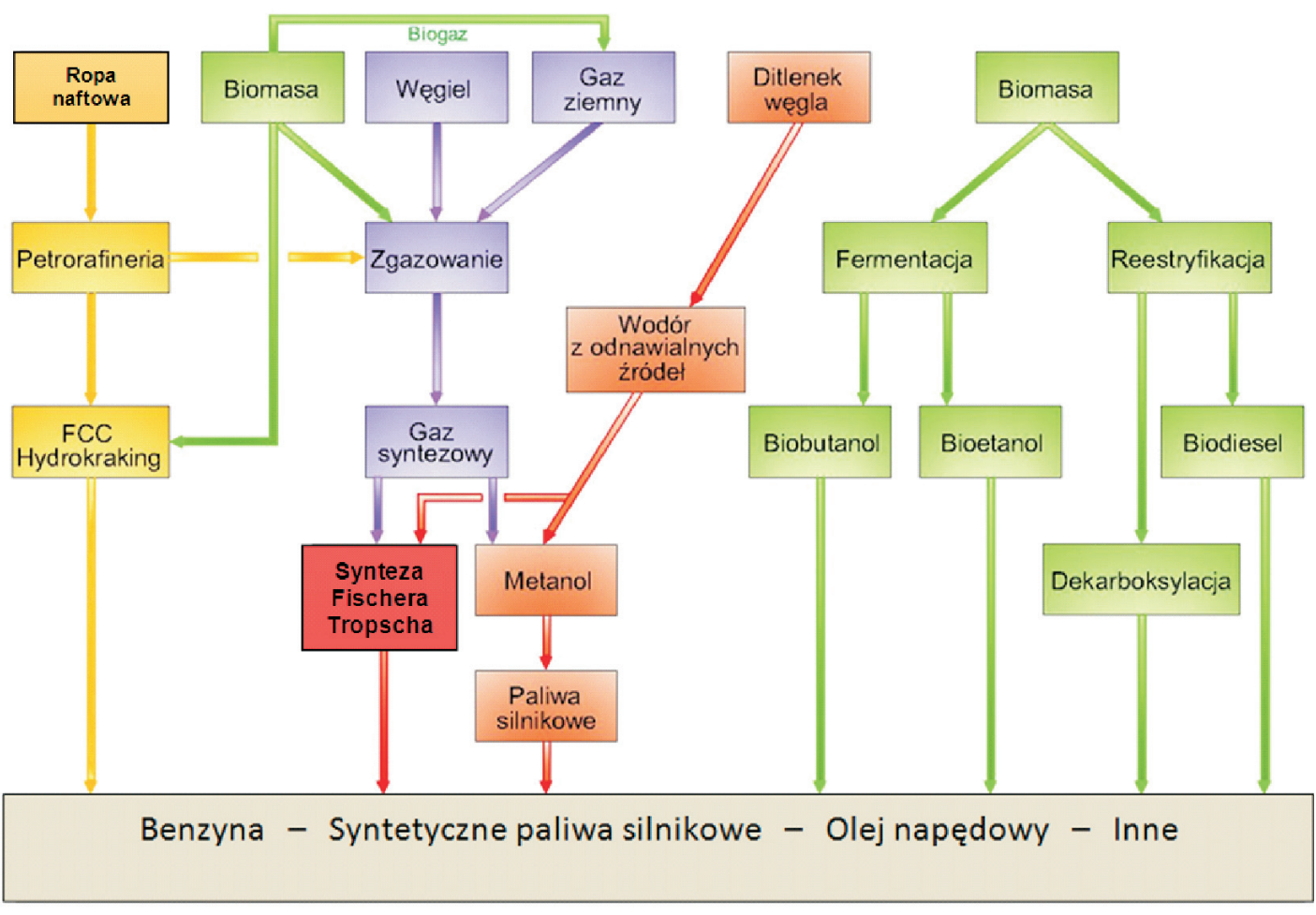

Fig. 2. Conversion of oil, coal, natural gas, biomass and carbon dioxide into liquid automotive fuels [7]

Rys. 2. Przetwarzanie ropy naftowej, węgla, gazu ziemnego, biomasy oraz ditlenku węgla do płynnych paliw silnikowych [7] 
base chemicals and automotive fuels not only from coal, natural gas, crude oil and renewable sources but also from the waste carbon dioxide on a world scale in a short and long term prospect. The latter - according to the authors research - can be easily processed, with a high level of efficiency into methanol with the use of cheap hydrogen. Methanol itself is an automotive fuel and can be processed into:

- aromatic hydrocarbons,

- olefins,

- propylene,

- gasoline,

- dimethyl ether oligomers (a full value diesel fuel).

From $\mathrm{CO}_{2}$ and $\mathrm{H}_{2}$ we can produce hydrocarbons through catalytic chemical reaction by the method of FischerTropsch, yet as compared to the synthesis of methanol, with a much lower efficiency, let alone the much sophisticated equipment.

\section{Production of electrical energy and hydrogen}

Coal, crude oils and natural gas, aside from the production of usable heat, are still the main basis for the production of electrical energy. To this group of raw materials we need to add tidal and nuclear, wind geothermal, photovoltaic and biomass energy.

Power stations, based on the solar and wind energy operate with sizeable interruptions and different power levels. There may be numerous incidents of significant surplus of energy from these sources yet they are short in nature. There are many ways to effectively direct this energy in the world economy - production of hydrogen through water electrolysis. Hydrogen, is among other things a perfect automotive fuel - and it is extremely environment friendly.

Currently, the industry manufactures hydrogen from natural gas through catalytic steam reforming. For environmental reasons steam should be replaced with carbon dioxide even though carbon dioxide is less advantageous in terms of economy.

Much hydrogen is still manufactured through gasification of coal and heavy oils coming from the processing of crude oil. Another source of hydrogen is the coke oven gas.

Recently a process of photocatalytic water splitting into hydrogen and oxygen has been developed. The specialists in the world economy hope that upon its full exploration it will constitute a source of cheap hydrogen [5].

In the analysis of the processes of hydrogen production from biomass we can differentiate thermal and non-thermal processes. While direct gasification of biomass with oxygen and gasification of biomasss with the use of water under supercritical parameters is a thermal process, photosynthetic and fermentation processes do not require much energy [8]. Biological processes (wet biomass) fall into that category. They do not require complex processing installations, which significantly influences its profitability. Here, hydrogen is produced from glucose being the main biomass component according to the reaction:

$$
\mathrm{C}_{6} \mathrm{H}_{12} \mathrm{O}_{6}+6 \mathrm{H}_{2} \mathrm{O}=12 \mathrm{H}_{2}+6 \mathrm{CO}_{2}
$$

perspektywie czasowej, uwzględnić wytwarzanie bazowych chemikaliów, a także paliw silnikowych nie tylko z węgla, gazu ziemnego, ropy naftowej oraz odnawialnych źródeł energii, ale również $\mathrm{z}$ odpadowego w gospodarce ditlenku węgla. Ten ostatni - według badań autorów - można z tanim wodorem przetwarzać w bardzo prosty sposób z ogromną wydajnością na metanol. On sam jest paliwem silnikowym i bywa przetwarzany (między innymi) na:

- węglowodory aromatyczne,

- olefiny,

- propylen,

- benzynę,

- oligomery eteru dimetylowego, będące pełnowartościowym paliwem do silników wysokoprężnych.

$\mathrm{Z} \mathrm{CO}_{2}$ i $\mathrm{H}_{2}$ można katalitycznie wytwarzać również węglowodory metodą Fischera-Tropscha, lecz w porównaniu z syntezą metanolu ze znacznie niższą wydajnością i w dodatku na bardziej skomplikowanych instalacjach.

\section{Wytwarzanie energii elektrycznej oraz wodoru}

Węgiel, oleje z ropy naftowej oraz gaz ziemny są wciąż jeszcze główną bazą wytwarzania energii elektrycznej obok ciepła użytkowego. Do tych surowców trzeba doliczyć energię wody oraz nuklearną, obok których rozwijają się: energetyka wiatrowa, geotermalna, fotowoltaiczna oraz wykorzystująca biomasę.

Elektrownie, bazując na promieniowaniu słonecznym i energii wiatru pracują z dużymi przerwami oraz $\mathrm{z}$ różną mocą. Liczne są, ale krótkotrwałe okresy, kiedy występują pokaźne nadwyżki energii elektrycznej z tych źródeł. Wśród rozmaitych procesów ich efektywnego zagospodarowania rosnace znaczenie w gospodarce światowej nabiera wytwarzanie wodoru na drodze elektrolizy wody. Wodór jest - między innymi - doskonałym paliwem dla silników samochodowych, a w dodatku nie szkodzi środowisku.

Obecnie wodór jest wytwarzany w gospodarce światowej przede wszystkim z gazu ziemnego na drodze katalitycznego reformingu parowego. Ze względów ekologicznych należy jak najszybciej zastąpić w tym procesie parę wodną ditlenkiem węgla i to mimo faktu, że ten bywa mniej korzystny ekonomicznie.

Wciąż jeszcze sporo wodoru wytwarza się na drodze zgazowania węgla oraz ciężkich olejów z przerobu ropy naftowej. Poza tym znaczną ilość wodoru uzyskuje gospodarka światowa z gazu koksowniczego.

Ostatnio odkryto proces bezpośredniego rozszczepiania wody do wodoru oraz tlenu z udziałem fotokatalizy - photocatalitic water splitting. Specjaliści gospodarki światowej wiążą z tą technologią przekonanie, że po jej pełnym rozpoznaniu uzyska się na tej drodze tani wodór [5].

Przy rozpatrywaniu wytwarzania wodoru z biomasy rozróżnia się procesy termiczne oraz nietermiczne. Podczas gdy bezpośrednie zgazowanie biomasy tlenem oraz zgazowanie z zużyciem wody w nadkrytycznych parametrach zalicza się do procesów termicznych, to obok nich dysponuje się technologiami fotosyntetycznymi oraz fermentacyjnymi, które nie wymagają wielkich ilości energii [8]. Do nich zaliczają się procesy biologiczne, przetwarzające zawodnioną biomasę. 


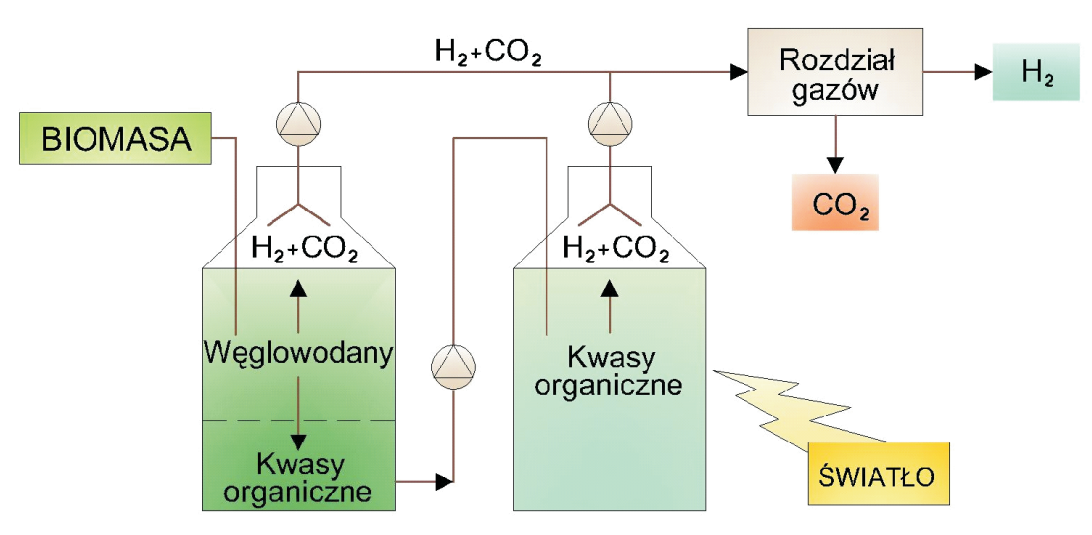

Fig. 3. Process diagram for conversion of wet biomass into hydrogen, via organic acids with the use of bacteria and light [8]

Rys. 3. Schemat aparatury przemiany zawodnionej biomasy na kwasy organiczne z udziałem bakterii oraz światta do wodoru [8]
Nie wymagają one wielkich instalacji przetwórczych, co ma znaczący wpływ na ich opłacalność. Tu wodór uzyskuje się z glukozy, będącej głównym komponentem biomasy według reakcji:

$$
\mathrm{C}_{6} \mathrm{H}_{12} \mathrm{O}_{6}+6 \mathrm{H}_{2} \mathrm{O}=12 \mathrm{H}_{2}+6 \mathrm{CO}_{2}
$$

Powszechnie wiadomo, że istnieją mikroorganizmy, które $\mathrm{w}$ procesie anaerobowym zarówno $\mathrm{w}$ warunkach mezofilowych $\left(25-40^{\circ} \mathrm{C}\right)$, termofilowych $\left(40-65^{\circ} \mathrm{C}\right)$, jak i ekstremalnie termofilowych $\left(65-80^{\circ} \mathrm{C}\right)$ przetwarzają biomasę na kwas octowy i wodór. Poza tym istnieją bakterie, które przez fotosyntezę są w stanie przetwarzać kwasy organiczne na wodór według reakcji:
It is generally known that there are microorganisms that, in the anaerobic process in mesophilic $\left(25-40^{\circ} \mathrm{C}\right)$, thermophilic $\left(40-65^{\circ} \mathrm{C}\right)$ and extremely thermophilic conditions $\left(65-80^{\circ} \mathrm{C}\right)$ can process biomass into acetic acid and hydrogen. Besides, there are bacteria that can process organic acids into hydrogen through photosynthesis according to the reaction:

and

$$
\mathrm{C}_{6} \mathrm{H}_{12} \mathrm{O}_{6}+4 \mathrm{H}_{2} \mathrm{O}=8 \mathrm{H}_{2}+4 \mathrm{CO}_{2}+\mathrm{CH}_{3} \mathrm{COOH}
$$

$$
\mathrm{CH}_{3} \mathrm{COOH}+2 \mathrm{H}_{2} \mathrm{O}+\text { light }=4 \mathrm{H}_{2}+2 \mathrm{CO}_{2}
$$

In a simple apparatus presented in Fig. 3.

\section{Catalytic synthesis of $\mathrm{CO}_{2}+3 \mathrm{H}_{2}$ into methanol}

Currently, in the world methanol is manufactured mainly through synthesis of $\mathrm{CO}+\mathrm{H}_{2}$ with the use of copper catalysts where the substrates are: natural gas, coal, heavy remains of the vacuum crude oil distillation, a variety of biomass and certain organic waste. Yet, the problem of climate protection becomes a burning issue, that forces a quick reduction in the emission of carbon dioxide into the atmosphere. The solution to the problem lies in the idea of pumping of this greenhouse gas into the geological structures with the use of a variety of techniques. Most of these techniques are unfortunately very complex, costly and energy inefficient not to mention the fact that there is no certainty whether in the course of time $\mathrm{CO}_{2}$ will not penetrate back into the atmosphere.

Based on the above logic, forms a concept of research on the processing of the waste carbon dioxide and hydrogen into both methanol and synthetic oil according to the reaction:

$$
\mathrm{CO}_{2}+3 \mathrm{H}_{2}=\mathrm{CH}_{3} \mathrm{OH}+\mathrm{H}_{2} \mathrm{O} \quad-49.6 \mathrm{~kJ} / \mathrm{mol}
$$

and

$$
\mathrm{CO}_{2}+3 \mathrm{H}_{2}=(\mathrm{H}-\mathrm{C}-\mathrm{H})+2 \mathrm{H}_{2} \mathrm{O} \quad-125.2 \mathrm{~kJ} / \mathrm{mol}
$$

$$
\mathrm{C}_{6} \mathrm{H}_{12} \mathrm{O}_{6}+4 \mathrm{H}_{2} \mathrm{O}=8 \mathrm{H}_{2}+4 \mathrm{CO}_{2}+\mathrm{CH}_{3} \mathrm{COOH}
$$

oraz

$$
\mathrm{CH}_{3} \mathrm{COOH}+2 \mathrm{H}_{2} \mathrm{O}+\text { światło }=4 \mathrm{H}_{2}+2 \mathrm{CO}_{2}
$$

i to w prostej aparaturze, zaprezentowanej na rys. 3 .

\section{Katalityczna synteza $\mathrm{CO}_{2}+3 \mathrm{H}_{2}$ do metanolu}

Obecnie na świecie metanol wytwarza się głównie na drodze syntezy $\mathrm{CO}+\mathrm{H}_{2}$ przy użyciu miedziowych katalizatorów, a surowcami są: gaz ziemny, węgiel, ciężka pozostałość z próżniowej destylacji ropy naftowej, różne rodzaje biomasy oraz określone odpady organiczne. Tymczasem szybko powiększa się problem ochrony klimatu, który wymusza jak najszybsze ograniczenie emisji ditlenku węgla do atmosfery. Rozwiązanie tego problemu sprowadza się przede wszystkim do wtłaczania tego gazu cieplarnianego do struktur geologicznych różnymi technikami. Niestety, są one w większości skomplikowane, kosztowne oraz energochłonne, a także nie ma pewności, czy z biegiem czasu $\mathrm{CO}_{2}$ nie przeniknie z powrotem do atmosfery.

Na tle powyższego rozumowania wyłania się koncepcja badań nad przetwarzaniem odpadowego ditlenku węgla z wodorem, zarówno na metanol, jak i na ropę syntetyczna według reakcji:

$$
\mathrm{CO}_{2}+3 \mathrm{H}_{2}=\mathrm{CH}_{3} \mathrm{OH}+\mathrm{H}_{2} \mathrm{O}
$$

oraz

$$
\mathrm{CO}_{2}+3 \mathrm{H}_{2}=(\mathrm{H}-\mathrm{C}-\mathrm{H})+2 \mathrm{H}_{2} \mathrm{O} \quad-125,2 \mathrm{~kJ} / \mathrm{mol}
$$

przy czym tu występuje reakcja pośrednia

$$
\mathrm{CO}_{2}+\mathrm{H}_{2}=\mathrm{CO}+\mathrm{H}_{2} \mathrm{O}
$$




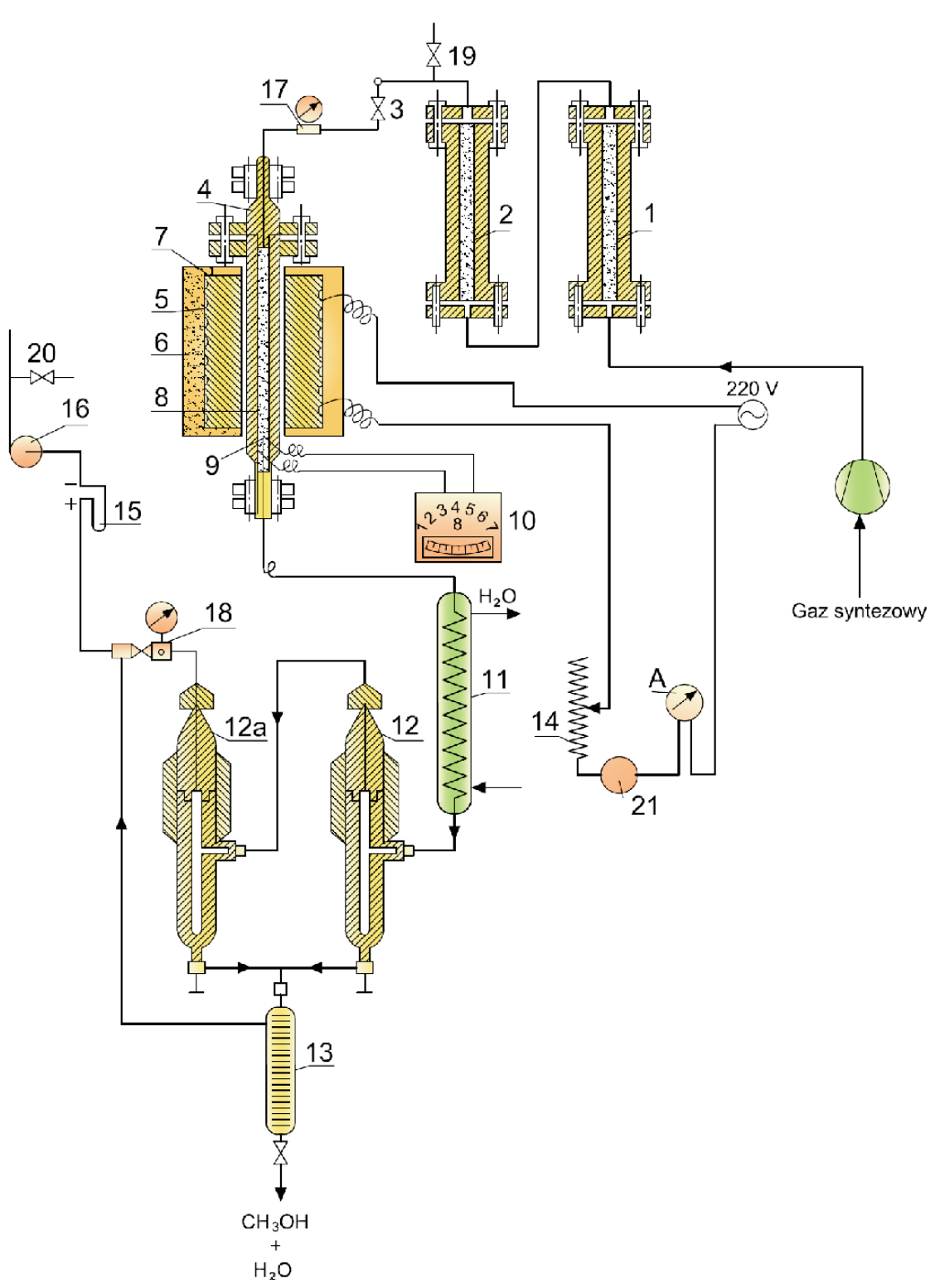

Fig. 4. A diagram of laboratory installation for the synthesis of methanol [4]: 1 - filter with copper chips, 2 - filter with activated carbon, 3 - needle valve, 4 - integral reactor, 5 - electric radiator, 6 - ceramic insulation coat, 7 - aluminium block, 8 - pressure reactionary pipe, 9 - thermocouple, 10 - temperature indicator and recorder (multipoint), 11 - condenser, 12, 12a - separator, 13 - methanol degassing reservoir, 14 - autotransformer, 15 - gas flow rate sensor, 16 - gas flow meter, 17, 18 - pressure sensor, 19, 20 - gas samples uptake to chromatograph, 21 - electric power supply

Rys. 4. Schemat laboratoryjnej instalacji do syntezy metanolu [4]: 1-filtr z wiórami miedzianymi,

2 - filtr z węglem aktywnym, 3 -zawór iglicowy, 4 - reaktor całkowy, 5 - grzejnik elektryczny, 6 - ceramiczny płaszcz izolacyjny, 7 - blok aluminiowy, 8 - ciśnieniowa rura reakcyjna, 9 - termopara, 10 - wskaźnik i rejestrator temperatury (wielopunktowy), 11 - kondensator, 12, 12a-separatory, 13 - zbiornik degazacji metanolu, 14 - autotransformator, 15 - pomiar natężenia przeptywu gazu, 16 - licznik przepływu gazu, 17, 18 -pomiar ciśnienia, 19, 20-pobór próbek gazu do chromatografu,

$$
21 \text { - zasilanie elektryczne }
$$

in this example however an intermediate reaction occurs

$$
\mathrm{CO}_{2}+\mathrm{H}_{2}=\mathrm{CO}+\mathrm{H}_{2} \mathrm{O}
$$

Both main processes of the synthesis are heavily exothermic and practically in the industry they will be realized in reactors of a boiler type in a vertical configuration or in the
Obydwa główne procesy syntezy są silnie egzotermiczne i w praktyce przemysłowej będa realizowane w reaktorach o konstrukcji kotłowej w układzie pionowym lub $\mathrm{w}$ reaktorach $\mathrm{z}$ suspensyjną fazą katalizatora. W rurkach umieści się katalizator, na którym będzie przebiegał jeden $\mathrm{z}$ powyższych procesów, natomiast między rurkami znajdzie się woda pod określonym ciśnieniem, która dzięki ciepłu wydzielonemu w reakcji syntezy $\mathrm{CO}_{2}+\mathrm{H}_{2}$ ulegnie zamianie $\mathrm{w}$ parę, niezbędną $\mathrm{w}$ każdej fabryce chemicznej.

Zastosowaną aparaturę badawczą dla syntezy $\mathrm{CO}_{2}+\mathrm{H}_{2}$ do metanolu zaprezentowano na rys. 4 i 5.

Reaktor wykonano ze stali austenitycznej 1H18N9T o średnicy 28/16 mm i wysokości 600 $\mathrm{mm}$. Na nim znajduje się płaszcz aluminiowy ze spiralą grzewczą. Zastosowano katalizator $\mathrm{CuO}-$ $\mathrm{ZnO}-\mathrm{Al}_{2} \mathrm{O}_{3}$ o składzie 47,54\% mas. $\mathrm{Cu}, 21,67 \% \mathrm{Zn}$ i 3,21\% Al, o granulacji $3 \mathrm{~mm}$. Po załadowaniu katalizatora przeprowadzono jego redukcję mieszaniną wodoru $\mathrm{z}$ azotem przy zmieniającym się ich stosunku od 1 : 20 do $10: 1$ pod ciśnieniem $1 \mathrm{MPa}$ w temperaturze 415-495 K, w czasie 9 godzin. Spośród wszystkich tlenków metali jedynie $\mathrm{CuO}$ ulega redukcji do (silnie piroforycznej) postaci metalicznej. Badania nad syntezą metanolu $\mathrm{z} \mathrm{CO}_{2}+3 \mathrm{H}_{2}$ wykonano pod ciśnieniem 5-10 $\mathrm{MPa}$, w temperaturze w zakresie 500-535 K oraz z udziałem 15-30\% obj. ditlenku węgla $\mathrm{w}$ mieszaninie $\mathrm{z}$ wodorem. Uzyskano zadowalającą wydajność, co dokumentuje rys. 6.

$\mathrm{Z}$ gazu zawierającego $78,8 \%$ obj. $\mathrm{H}_{2}$ oraz $20,6 \mathrm{CO}_{2}$ uzyskano nieco ponad $1000 \mathrm{~g} \mathrm{CH}_{3} \mathrm{OH} \mathrm{z} 1 \mathrm{~kg}$ katalizatora na godzinę w temperaturze $525 \mathrm{~K}$, pod ciśnieniem $8 \mathrm{MPa}$ i przy szybkości objętościowej substratu (gazu) wynoszącej $25000 \mathrm{dm}^{3} / \mathrm{kg} \cdot \mathrm{h}$. Uzyskano potrzebne dane do projektu bazowego wielkoprzemysłowej instalacji syntezy metanolu z $\mathrm{CO}_{2}+3 \mathrm{H}_{2}$. Zawartość produktów ubocznych, poza wodą, nie przewyższała $0,4 \%$ masy. 
reactors with a suspensive catalytic phase. The catalyst will be located in the pipes on which one of the above processes will take place and between the pipes water of a given pressure will turn into steam (steam is necessary in any chemical plant) thanks to the heat released from the reaction of synthesis of $\mathrm{CO}_{2}+\mathrm{H}_{2}$.

The applied research equipment for the synthesis of $\mathrm{CO}_{2}+\mathrm{H}_{2}$ into methanol has been presented in Fig. 4, 5 .

The reactor was made from austenitic steel $1 \mathrm{H} 18 \mathrm{~N} 9 \mathrm{~T}$ of $28 / 16 \mathrm{~mm}$ in diameter and $600 \mathrm{~mm}$ in height. On the reactor an aluminium coat is fitted with a heater spiral. $\mathrm{ACuO}-\mathrm{ZnO}-\mathrm{Al}_{2} \mathrm{O}_{3}$ catalyst was applied with the composition $47.54 \%$ mass of $\mathrm{Cu}, 21.67 \% \mathrm{Zn}$ and $3.21 \% \mathrm{Al}$, of $3 \mathrm{~mm}$ granulation. After loading of the catalyst it was reduced with a mixture of hydrogen and nitrogen of the ratio $1: 20$ to $10: 1$ under a pressure of $1 \mathrm{MPa}$ in the temperature $415-495 \mathrm{~K}$ in the time of 9 hours. Out of all the metal oxides only $\mathrm{CuO}$ was reduced to a metallic form (heavily pyrophoric). The investigations on the methanol synthesis from $\mathrm{CO}_{2}+3 \mathrm{H}_{2}$ were performed under a pressure of 5-10 MPa, in the temperature range of $500-535 \mathrm{~K}$ with the participation of $15-30 \%$ vol. of carbon dioxide in a mixture with hydrogen. Satisfactory efficiency was obtained which is confirmed by Fig. 6 .

From the gas containing $78.8 \%$ vol. $\mathrm{H}_{2}$ and $20.6 \mathrm{CO}_{2}$ a little over $1000 \mathrm{~g} \mathrm{CH}_{3} \mathrm{OH}$ from $1 \mathrm{~kg}$ of the catalyst was obtained per hour in the temperature of $525 \mathrm{~K}$, under a pressure of $8 \mathrm{MPa}$ at the volumetric speed of the substrate (gas) of $25000 \mathrm{l} / \mathrm{kg} \cdot \mathrm{h}$. The data necessary for the base project of a large scale industrial methanol synthesis $\left(\mathrm{CO}_{2}+3 \mathrm{H}_{2}\right)$ installation were obtained. The content of byproducts, beside water, did not exceed $0.4 \%$ of the mass.

\section{Synthesis of $\mathrm{CO}_{2}+3 \mathrm{H}_{2}$ into hydrocarbons}

For the necessary investigations the above mentioned system was used as shown in Fig. 4. Under the synthesis reactors a $250 \mathrm{ml}$ container was installed to which hot paraffin dropped. Past the second separator in the row a column was installed absorbing light hydrocarbons from the post process gas in the fraction of liquid products in the boiling range of $455-515 \mathrm{~K}$. In the investigations on the synthesis of $\mathrm{CO}_{2}+3 \mathrm{H}_{2}$ into hydrocarbons a ferrous catalyst was used, activated with copper and potassium in the following mutual mass ratio: $100 \mathrm{Fe}: 6 \mathrm{Cu}: 3$ $\mathrm{K}_{2} \mathrm{O}$. This catalyst was loaded into the reactor in the form of ferrous and copper oxides from $\mathrm{K}_{2} \mathrm{CO}_{3}$ of $3 \mathrm{~mm}$ granulation. Its reduction was done with hydrogen in the temperature of 575-625 K in the time of 7 hours. Only ferrous and copper oxides reduce to a metallic form in this temperature. The investigations on the synthesis of $\mathrm{CO}_{2}+3 \mathrm{H}_{2}$ into synthetic oil were done in the temperature of $540-575 \mathrm{~K}$, under a pressure of 1.0-2.0 MPa with a $26-32 \%$ vol. participation of carbon dioxide in a mixture with hydrogen. In the temperature of $570 \mathrm{~K}$, under a pressure of $1.0 \mathrm{MPa}$ from the gas of the content of $31.4 \% \mathrm{vol}$. $\mathrm{CO}_{2}, 68.3 \% \mathrm{H}_{2}, 0.2 \% \mathrm{~N}_{2}$ and $0.1 \% \mathrm{CH}_{4} 72.6 \mathrm{~g}$ hydrocarbons were obtained with molecules above $\mathrm{C}_{2}$ per $1 \mathrm{~m}^{3}$ of the applied synthesis gas.

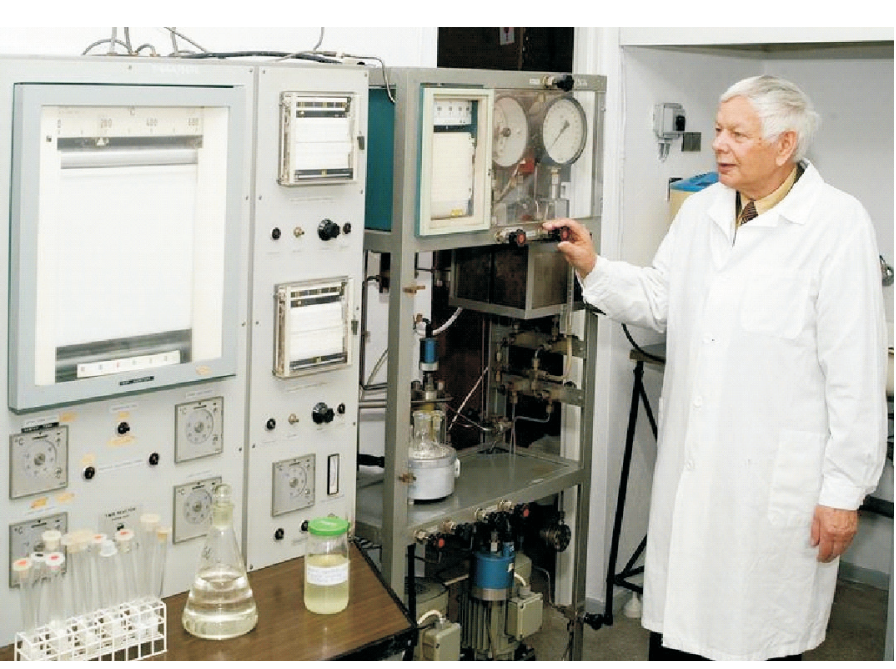

Fig. 5. A test stand for synthesis of methanol Rys. 5. Stanowisko badawcze do syntezy metanolu

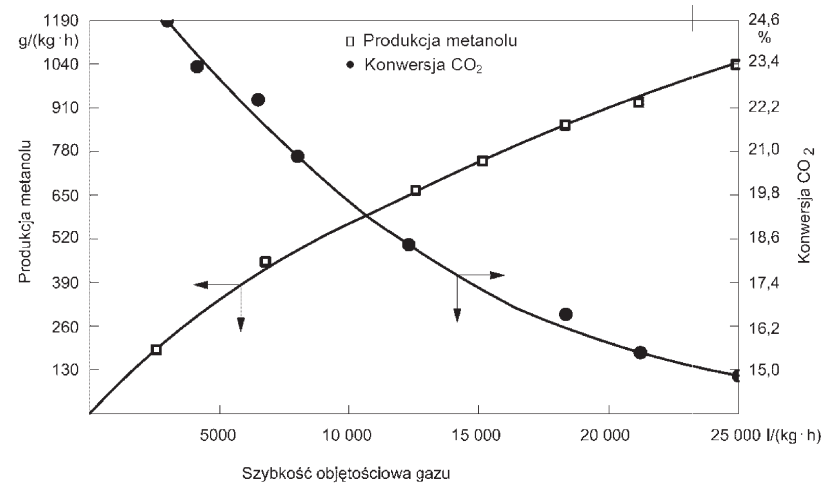

Fig. 6. Synthesis of methanol on $\mathrm{CuO}-\mathrm{ZnO}-\mathrm{Al}_{2} \mathrm{O}_{3}$ catalyst from gas with the following composition: $78.8 \% \mathrm{H}_{2}, 0.2 \% \mathrm{CH}_{4}, 0.4 \% \mathrm{~N}_{2}, 20.6 \%$ $\mathrm{CO}_{2}$, pressure $8 \mathrm{MPa}$, temperature $525 \mathrm{~K}$ [4]

Rys. 6. Synteza metanolu na katalizatorze $\mathrm{CuO}-\mathrm{ZnO}-\mathrm{Al}_{2} \mathrm{O}_{3}$ z gazu o sktadzie: $78,8 \% \mathrm{H}_{2}, 0,2 \% \mathrm{CH}_{4}, 0,4 \% \mathrm{~N}_{2}, 20,6 \% \mathrm{CO}_{2}$, ciśnienie $8 \mathrm{MPa}$, temperatura $525 \mathrm{~K}$ [4]

\section{Synteza $\mathrm{CO}_{2}+3 \mathrm{H}_{2}$ do węglowodorów}

Do niezbędnych badań wykorzystano omawianą wyżej instalację laboratoryjną, przedstawioną na rys. 4. Pod reaktorem syntezy zainstalowano zbiorniczek o pojemności $250 \mathrm{ml}$, do którego spływała gorąca parafina. Po drugim w szeregu separatorze zainstalowano kolumnę absorbującą lekkie węglowodory $\mathrm{z}$ gazu poprocesowego $\mathrm{w}$ frakcji ciekłych produktów o zakresie wrzenia $455-515 \mathrm{~K}$. W badaniach nad syntezą $\mathrm{CO}_{2}+3 \mathrm{H}_{2}$ do węglowodorów zastosowano katalizator żelazowy, aktywowany miedzią oraz potasem $\mathrm{w}$ następującym, wzajemnym stosunku masowym: $100 \mathrm{Fe}: 6$ $\mathrm{Cu}: 3 \mathrm{~K}_{2} \mathrm{O}$. Katalizator ten ładowano do reaktora w postaci tlenków żelaza oraz miedzi z $\mathrm{K}_{2} \mathrm{CO}_{3}$ o granulacji $3 \mathrm{~mm}$. Jego redukcję przeprowadzano wodorem $w$ temperaturze 575-625 $\mathrm{K}$ w czasie 7 godzin. Tylko tlenki żelaza i miedzi w tej temperaturze ulegają redukcji do postaci metalicznej. Badania nad syntezą $\mathrm{CO}_{2}+3 \mathrm{H}_{2}$ do ropy syntetycznej prowadzono w temperaturze $540-575 \mathrm{~K}$, pod ciśnieniem 1,0-2,0 MPa oraz $\mathrm{z}$ udziałem $26-32 \%$ obj. ditlenku węgla $\mathrm{w}$ mieszaninie $\mathrm{z}$ wodorem. W temperaturze $570 \mathrm{~K}$, pod ciśnieniem 1,0 MPa 
The product of the synthesis contained $9.5 \%$ mass of liquefied gas $\mathrm{C}_{3}-\mathrm{C}_{4}, 26.9 \%$ gasoline of boiling range up to $455 \mathrm{~K}, 18.6 \%$ kerosene of boiling of $455-505 \mathrm{~K}, 18.3 \%$ heavy diesel oil of boiling range of $505-635 \mathrm{~K}, 11.5 \%$ paraffin oil of boiling range of $635-735 \mathrm{~K}, 14.7 \%$ boiling paraffin $>735 \mathrm{~K}$ and $0.5 \%$ oxygen compounds in the form of alcohols and acids. The results are extremely promising and after a preliminary positive calculation justify the next step in the investigations conducted on a pilot scale.

\section{Conclusions}

The presented results of the investigations on the synthesis of carbon dioxide and hydrogen, into both methanol and synthetic oil should lead to a profitability of coal power stations withdrawing from the under ground storage of $\mathrm{CO}_{2}$ which has an adverse effect on the energy efficiency and as a consequence leads to a high growth in the prices of energy.

The authors are aware of the necessity to preserve common sense in their vision of a quick solution to the problem of $\mathrm{CO}_{2}$ utilization in the methanol synthesis. The knowledge of the chemical mechanism and technology of the mere synthesis becomes realizable only after a full understanding of the technology and creating a sufficient potential for mass, energy consuming hydrogen production. This particular issue constitutes the basic obstacle of any discussions and plans of usage of huge resources of carbon dioxide in a chemical synthesis.

Paper reviewed oraz z gazu o zawartości 31,4\% obj. $\mathrm{CO}_{2}, 68,3 \% \mathrm{H}_{2}, 0,2 \%$ $\mathrm{N}_{2}$ i $0,1 \% \mathrm{CH}_{4}$ uzyskano 72,6 g węglowodorów z cząsteczkami powyżej $\mathrm{C}_{2} \mathrm{w}$ przeliczeniu na $1 \mathrm{~m}^{3}$ zastosowanego gazu syntezowego.

Produkt syntezy zawierał 9,5\% mas. gazu płynnego $\mathrm{C}_{3}-\mathrm{C}_{4}, 26,9 \%$ benzyny o zakresie wrzenia do $455 \mathrm{~K}, 18,6 \%$ nafty o zakresie wrzenia 455-505 K, 18,3\% ciężkiego oleju napędowego o zakresie wrzenia $505-635 \mathrm{~K}, 11,5 \%$ oleju parafinowego o zakresie wrzenia $635-735 \mathrm{~K}, 14,7 \%$ parafiny wrzącej $>735 \mathrm{~K}$ oraz $0,5 \%$ związków tlenowych w postaci alkoholi i kwasów. Wyniki te trzeba uznać za wielce obiecujące, które po pozytywnej, wstępnej kalkulacji uzasadniają podjęcie kolejnego etapu badań w skali pilotowej.

\section{Podsumowanie}

Zaprezentowane wyniki badań nad syntezą ditlenku węgla $\mathrm{z}$ wodorem, zarówno do metanolu, jak i ropy syntetycznej powinny doprowadzić do ekonomicznej opłacalności elektrowni węglowych, zwolnionych od składowania $\mathrm{CO}_{2}$ pod ziemią, co niekorzystnie wpływa na sprawność energetyczną i w konsekwencji prowadzi do znacznego wzrostu cen energii elektrycznej.

Podsumowując, autorzy mają świadomość konieczności zachowania umiaru w wizji szybkiego rozwiązania problemu utylizacji $\mathrm{CO}_{2}$ w syntezie metanolu. Znajomość i opanowanie chemizmu i technologii samej syntezy staje się realne dopiero po opanowaniu technologii i stworzeniu odpowiedniego potencjału masowej, energochłonnej produkcji wodoru. I właśnie ta sprawa stanowi podstawowy ogranicznik wszelkich rozważań i planów wykorzystania w syntezie chemicznej olbrzymiej bazy surowcowej ditlenku węgla.

\section{Bibliography/Literatura}

[1] Claus P., Vogel G.H.: The Roll of Chemocatalysis in the Establishment of the Technology Platform „Renewable Resources”, Chemical Engineering \& Technology, Vol. 31, Issue 5, 2008, pp. 678-699.

[2] Diercks R., Arndt J.D., Freyer S., Geier R., Machhammer O., Schwartze J., Volland M.: Raw Material Changes in the Chemical Industry, Vol. 31, Issue 5, 2008, pp. 631-637.

[3] Kotowski W., Augustynowicz A.: New outlook manufacturing automotive alternative engine fuels, PTNSS-2009-SC-182, Combustion Engines 2009-SC, Opole - Bielsko-Biała, s. $422-427$.

[4] Kotowski W.: Szansa wykorzystania emitowanego ditlenku węgla w syntezie chemicznej, Karbo 1/2009, s. 21-23.

Prof. Włodzimierz Kotowski. DSc., DEng.-- Professor in the Faculty of Mechanical Engineering at Opole University of Technology.

Prof. dr hab. inż. Wlodzimierz Kotowski-profesor na Wydziale Mechanicznym Politechniki Opolskiej. e-mail:w.kotowski@po.opole.pl
[5] van Niel E.W.J., Budde M.A.W., de Haas G.G., van der Wal F.J., Claasen P.A.M., Stams A.J.M.: Distinctive Properties of High Hydrogen Producing Extreme Thermophiles, Caldicellulosiruptor saccharolyticus and Thermotoga elfii, International Journal of Hydrogen Energy 2002, Vol. 27, pp. 1391-1398.

[6] Schaub G.: Synthetic Fuels and Biofuels for the Transportation Sector - Principles and Perspectives, OIL GAS European Magazine. Vol. 32, 2006, pp. 34-38.

[7] Vogel G.H.: Change in Raw Material Base in the Chemical Industry. Chemical Engineering \& Technology, Vol. 31, Issue 5, 2008, pp. 730-735.

[8] de Vrije T., de Haas G.G., Tan G.B., Keijsers E.R.P., Classen P.A.M.: Pretreatment of Miscanthus for hydrogen production by Thermotoga elfii. International Journal of Hydrogen Energy, Vol. 27, 2002, pp. 1381-1390.

Mr. Andrzej Augustynowicz, DEng. - adiunkt in the Faculty of Mechanical Engineering at Opole University of Technology.

Dr inż. Andrzej Augustynowicz - adiunkt na Wydziale Mechanicznym Politechniki Opolskiej e-mail:a.augustynowicz@po.opole.pl 